\title{
Resisting extractive uses of the archive in Colombian experimental non-fiction
}

María A. Vélez-Serna

DOI:10.15664/fcj.v19i0.2380

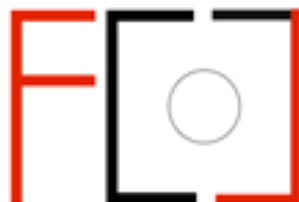

Frames Cinema Journal ISSN 2053-8812

Issue 19 (March 2022)

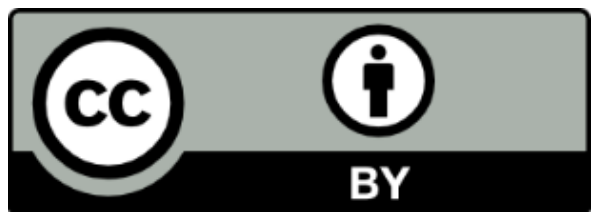




\section{Resisting extractive uses of the archive in Colombian experimental non-fiction}

María A. Vélez-Serna

In the first two decades of the $21^{\text {st }}$ century, a cluster of Colombian filmmakers started to develop a distinctive body of work engaging with the country's histories of violence through critical documentary and experimental devices. Juana Suárez has written about a generation of filmmakers with transnational histories whose work "shares a particular set of characteristics linked to aesthetics and forms of production", including a diasporic perspective on the national, connections with alternative funding and exhibition circuits, generic and linguistic hybridity, and a political approach to experimental practice. ${ }^{1}$ Filmmakers born in the 1970 s and 1980 s, including Camilo Restrepo, Laura Huertas Millán, Felipe Guerrero and Juan Soto have built substantial portfolios ranging across short film, features, and installation. ${ }^{2}$ Without imposing on them a unified identity, or defining the boundaries of a "movement", it is possible to see an expanding constellation of moving image works with overlapping interests and strategies. Central to this commonality is a critical relationship to archival moving image and found footage, expressed in a variety of ways to appropriate, intervene. and juxtapose source materials. These strategies engage with the materiality of analogue and digital images, often retaining traces of their provenance and mediation. In doing this, the films can embody a reflection on the filmmaker's access to appropriated images and challenge the spectator to question their own viewing position.

While this article follows emerging scholarship that recognises such a cluster of characteristics in Colombian filmmakers specifically, this must be understood in the context of broader shifts in documentary practice, particularly in Latin America. ${ }^{3}$ María Luisa Ortega observes that, in contemporary documentary, existing images are appropriated, re-edited and often re-filmed in ways that "emphasise the material (objectual) nature of images" and explore "the traces of their 
(ideological) origins". 4 Maria Luna and Carolina Sourdis consider whether there is a "specifically Latin American approach to found footage", which may be more explicitly politicised than the kinds of experimental collage practices studied in other contexts. ${ }^{5}$ According to Luisa Fernanda Ordóñez, "Latin American nonfiction films have approached the past, the present, and memory in diverse assemblages that combine autobiography, family history, and reflections about identity". ${ }^{6}$ In Argentina and Chile, for instance, those who were too young to remember the dictatorships have reopened questions that were pushed aside in the transition to neoliberal democracy, refusing a status quo that depends on forgetting the brutality of the regime and, moreover, the complicity of many citizens. In Colombia, the transition towards a state of "post-conflict" has been repeatedly delayed by the collapse or betrayal of multiple peace negotiations with different actors. Instead of a linear endpoint, there is a history of fluctuating intensities and geographies of the conflict. Sourdis and Luna find that this results in approaches to the archive that reflect political fragmentation but also a nostalgia for unity. ${ }^{7}$ Rather than nostalgia, Suárez finds that this group of contemporary filmmakers approach the archive with "suspicion", and struggle against the narrative pull of the idea of the nation. ${ }^{8}$

There are generational factors that may be relevant to this perspective. There is no consensus on the temporal boundaries of Colombia's internal conflict, as it has shifted its intensity, territorialisation, actors, methods, and frames of reference so many times. Over more than fifty years, the war has "transformed itself and transformed the country". 9 By 2012, when peace negotiations started with FARC, over 220,000 people had been killed and millions had been displaced. Within this extended timeline, the late 1980s and early 1990s were a critical juncture. Cocaine cartels had a grip on every level of political and economic power; landowner-backed paramilitary groups massacred peasants and opposition politicians in collaboration with the army; guerrilla groups kidnapped civilians, ran drug routes and blew up infrastructure. A glimmer of hope had appeared with a series of peace accords leading to the demobilisation of 
guerrilla factions, who were then betrayed and persecuted. The filmmakers discussed here lived through these years as children or adolescents, and they share an impulse to revisit these histories. Lacking the sense of closure of a "post-conflict" narrative, these explorations often adopt less linear forms, weaving together overlapping and ongoing pasts.

The films I discuss in this article engage with historical events through different strategies of mediated representation. Their "suspicion of the archive" (to use Suárez's term) is performed through formal and rhetorical devices that complicate a simply indexical or nostalgic archive effect. ${ }^{10}$ This critique, however, does not stop at questioning the veracity or completeness of the archive. More fundamentally, the material traces of archival mediation serve to denaturalise the use of found footage through reflexivity and distancing. In other words, the films question the filmmaker's prerogative to display, and the audience's right to consume audio-visual evidence.

To understand the ethical and political nuances in these filmmakers' use of found footage and archive material, I use extractivism as a critical lens. In a structural sense, "contemporary neoextractivism refers to a way of appropriating nature and a development model based on the over-exploitation of natural goods [...] characterized by its large scale and its orientation towards export". ${ }^{11}$ As Imre Szeman and Jennifer Wenzel put it, in extractivism, "“natural resources' are taken out of one geographic location - often on a colonial periphery - and utilised as 'raw materials', that is, as inputs to industrial processes elsewhere". ${ }^{12}$ This is a material process tied to an ideology, a "logic of extraction", which includes extractive seeing or extractive visuality. Macarena Gómez-Barris defines "the extractive view" as one that renders territories as commodities. It is related to the colonial gaze that sees territories as empty or up for grabs, and "facilitates the reorganization of territories, populations, and plant and animal life into extractible data and natural resources for material and immaterial 
accumulation."13 Extractivism cannot function without these abstractions; however, it is important not to lose from the analysis the material dimension of extraction.

These material and symbolic frameworks of extractivism offer a way to question how source materials - in this case, the images and testimonies of violence - are mobilised in new film works as they circulate internationally. This opens up critical perspectives on the transformation of media images of the Colombian conflict into a visual and narrative commodity that can be marketed abroad, and how critical filmmakers negotiate or resist this commoditisation. In the appropriation of existing footage there is an act of displacement, where a resource is taken from one place and transformed into a new commodity that can enter markets elsewhere. The archive, then, can be a site of extraction, but also of resistance. I propose this framing with reservations, keeping in mind Szeman and Wenzel's warning against the "conceptual creep" of using extractivism to describe relationships that are beyond the instrumentalisation of nature, for instance by applying it to texts, a "metaphorization" that dematerialises this approach and risks "losing the very thing that gives extractivism its conceptual bite". ${ }^{14}$ The materiality of the archive and practices of appropriation must then be at the centre of this analysis, linked with the films' refusal of national representation, legibility, and spectacle.

In the following discussion, I identify three structural patterns through which this resistance is articulated in specific films from this group of filmmakers. Firstly, I approach the work of Camilo Restrepo, in particular his early short film Tropic Pocket (2011), as it demonstrates the use of formal strategies (visual texture and sound) to disrupt the ethnographic gaze. I then look at Laura Huertas Millán's work The Labyrinth (2018) as an inversion of dominant patterns of archival appropriation that acknowledge the role of fictions in shaping the material world. The final part of the essay considers the autobiographical encounter with news footage in Oslo, 
2012 (2014) by Juan Soto, alongside works by Federico Atehortúa and Marta Hincapié. I argue that these strategies articulate positions of adjacency to the Colombian conflict. They offer alternatives to the illusory transparency of witnessing, by grappling with mediated relationships with historical events.

\section{Tropic Pocket: Anticolonial illegibility}

Camilo Restrepo's work is explicitly concerned with the imbrication of past and present, through palimpsestic and non-linear forms. Trained as a painter, Restrepo questions found images through the intervention of sound and surface. ${ }^{15}$ As Janet Stewart argues, if extractive seeing is the dominant logic, "retaining a certain illegibility" can be a way of countering its totalising effects. ${ }^{16}$ It stops the material from becoming data, from being accumulated into colonial currency. ${ }^{17}$ Working on analogue formats, Restrepo lets deterioration, fragmentation and low resolution interrupt the indexical reading of appropriated footage. Throughout several of his later works, most saliently Impression of a War (2015) and Los Conductos (2020), there is an interest in inscription, printing and marking on paper, fabric, or skin, which draws attention to the materiality of the film image. Appropriated footage is treated as such an inscription, a sign with a history rather than an automatic record of reality.

Restrepo's first film, Tropic Pocket, is a 10-minute, fast-paced short. Based on an investigation (both remote and on-site) of the region of Chocó in Colombia, the film consists of black-and-white and colour 8mm footage shot by Restrepo, and three disparate archival sources he found online while researching the area. As Suárez argues, this apparently unsystematic method using regular search engines is a critical strategy: "Restrepo shares a frustration with historical models, a suspicion towards images and the way they are organised in state archives [...] his films open up a space for images found by chance". ${ }^{18}$ Furthermore, having found the images online, Restrepo captures them on analogue supports, not in order to 
erase their digital origins but to maintain the traces of their unsanctioned archival transmutations.

The oldest source from which fragments are included in Tropic Pocket is a feature-length fictionalised account of a Claretian missionary evangelising indigenous and Afro-Colombian communities, shot in $16 \mathrm{~mm}$ colour in the late 1950 s by one of the priests. ${ }^{19}$ This film combines documentary images of religious ceremonies and community work with a staged narrative about an attack on the missionary by an Afro-Colombian sorcerer, which seems both intended to increase the entertainment appeal of the film and to give a sense of peril and adventure to missionary work. The second source is a 1961 promotional film, which captures the attempt to cross the Darién gap on three Chevrolet Corvairs in order to demonstrate the cars' toughness. This was produced by the Jam Handy organisation, a prolific maker of sponsored films that had close ties with Detroit carmakers. ${ }^{20}$ Finally, Restrepo uses videos uploaded by Colombian army soldiers and guerrilla combatants. Tropic Pocket ends with title cards outlining these sources, but the footage is otherwise unmarked within the film.

As Jaimie Baron writes, experiencing footage as archival entails an apprehension of temporal and intentional disparity; the viewer perceives that the images were produced at a different time and for a different purpose than those of the film they are watching. ${ }^{21}$ This "archive effect" most often results from the perception of differences in format and medium, such as the grain and blur of small-gauge film or the magnetic artifacts of analogue video, contrasting with the sharper images expected of each new audio-visual technology. In Tropic Pocket, however, these perceptual differences do not work in the expected manner. The surface of the image does not allow for a straightforward distinction between analogue and digital points of origin. The three archival sources are both digital and analogue images. In the case of Isla de los Deseos and Chevrolet Corvair (the two films described in the previous paragraph), the $16 \mathrm{~mm}$ prints 
exist in archives, but Restrepo has used the poor-quality video transfers available online. In this remediated form, these sponsored institutional films thus inhabit the same platforms, the same encodings, the same computer screens as the videos shot by combatants on their phones. The perceptual traces that induce the archival effect are disorientating, as each image has undergone several transfers from analogue to digital or vice-versa and is presented digitally. The combined artifacts of digital compression and small-gauge film, as well as Restrepo's choice to remove colour from most - but not all - of the footage, work to resist linear time and to inhibit restorative readings of these archives. Rather than presenting a nostalgic analogue past in contrast with a violent digital present, Restrepo's film implies that past and present are simultaneous and inseparable, as both the recent and older archives speak of the forces that have laid claim to the Chocó region, revealing "a relation of domination that is ceaselessly renewed".22

The older archival films used by Restrepo enact forms of extractive seeing. In both cases, the territory and its inhabitants are seen as challenges to be conquered, through persuasion or force. Restrepo thus mobilises these films against each other to expose this colonial standpoint - not as something of the past, but as an ongoing violence. This is articulated through the soundtrack and the narration. After a first silent sequence, sound comes in, but vivid animal calls are soon interrupted by insect buzzing and chainsaw engines. These loud, violent sound segue into an over-revving car engine, which marks the introduction of the Corvair images. Here, the voiceover from the missionary film is laid over the images of the car struggling through jungle rivers and hills. This juxtaposition continues with the narration displaced to the subtitles, while distorted, rhythmic music and snippets of audio from the films constitute a disquieting soundtrack. The narration from Isla de los Deseos, in which a missionary tells a boy about his evangelisation methods, reaches a crisis as the car journey ends. The rest of the film gestures towards more recent forms of violence with the combatant images and performance, while the 
fictional narration continues with a reference to a community under attack from pirates. The multiple layers of image, sound and narrative produce a tension, as the impulse is to interpret the images in light of the narration, but this is much more difficult here than in the first section. The final section of the film then resolves into cathartic movement, with some distorted champeta music and frenetic dancing.

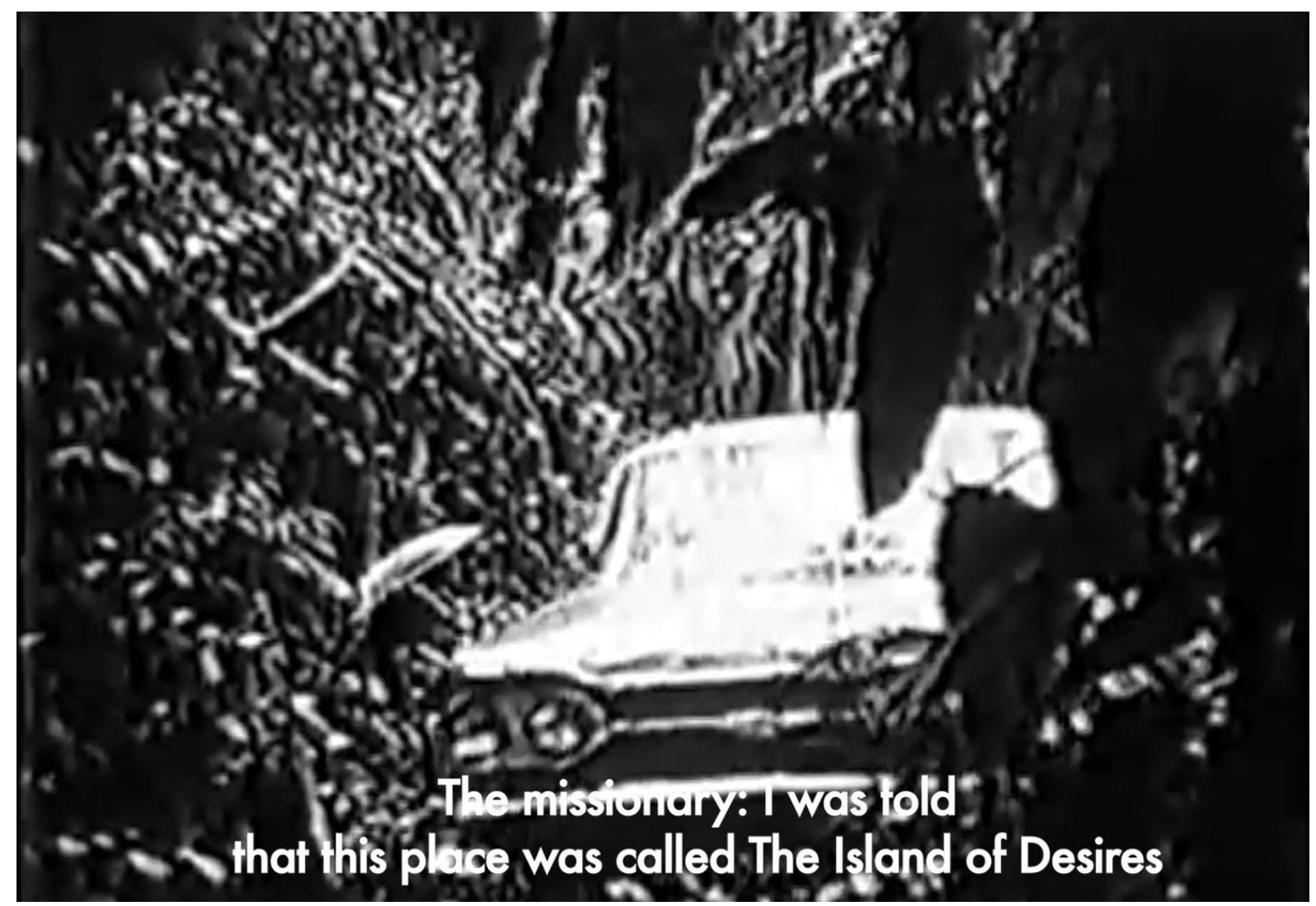

Figure 1. Tropic Pocket (Camilo Restrepo, 2011). The car pushing through the jungle (from Chevrolet's Daring the Darien! sponsored film) is presented in low-resolution black-and-white, with subtitle narration coming from the missionary film La isla de los deseos

For Tropic Pocket, Restrepo filmed the digital archives he was working with on Super8. ${ }^{23} \mathrm{He}$ justifies this as a distancing strategy, against the hyper-realism of sharp digital images, and also as an attempt to "de-instrumentalise" these sources, all of which are "vehicles of colonising ideologies". ${ }^{24}$ However, the images' coloniality is stubborn; they remain more legible than the more recent footage, so that paradoxically meaning becomes more unstable the closer we are to the present. The very short fragments potentially recognisable as combatant footage include 
a walk through tall grass to find a dead dog, and an explosion, both filmed in low resolution and with blocky compression artifacts. The footage shot by Restrepo in the village of San Francisco is sometimes frenetic with the movement of bodies, sometimes reaching for symbolism through performance and everyday objects. It again demonstrates a distance, a deliberate incomprehension. In this film, it is the contemporary images that are enigmatic, while the archival ones are obvious but obfuscated. Using non-representational performance, shaky camerawork and distorted sound, the filmmaker refuses to produce recordings that can be abstracted as "data" and therefore participate in the extractive logics that previous imagemaking enabled.

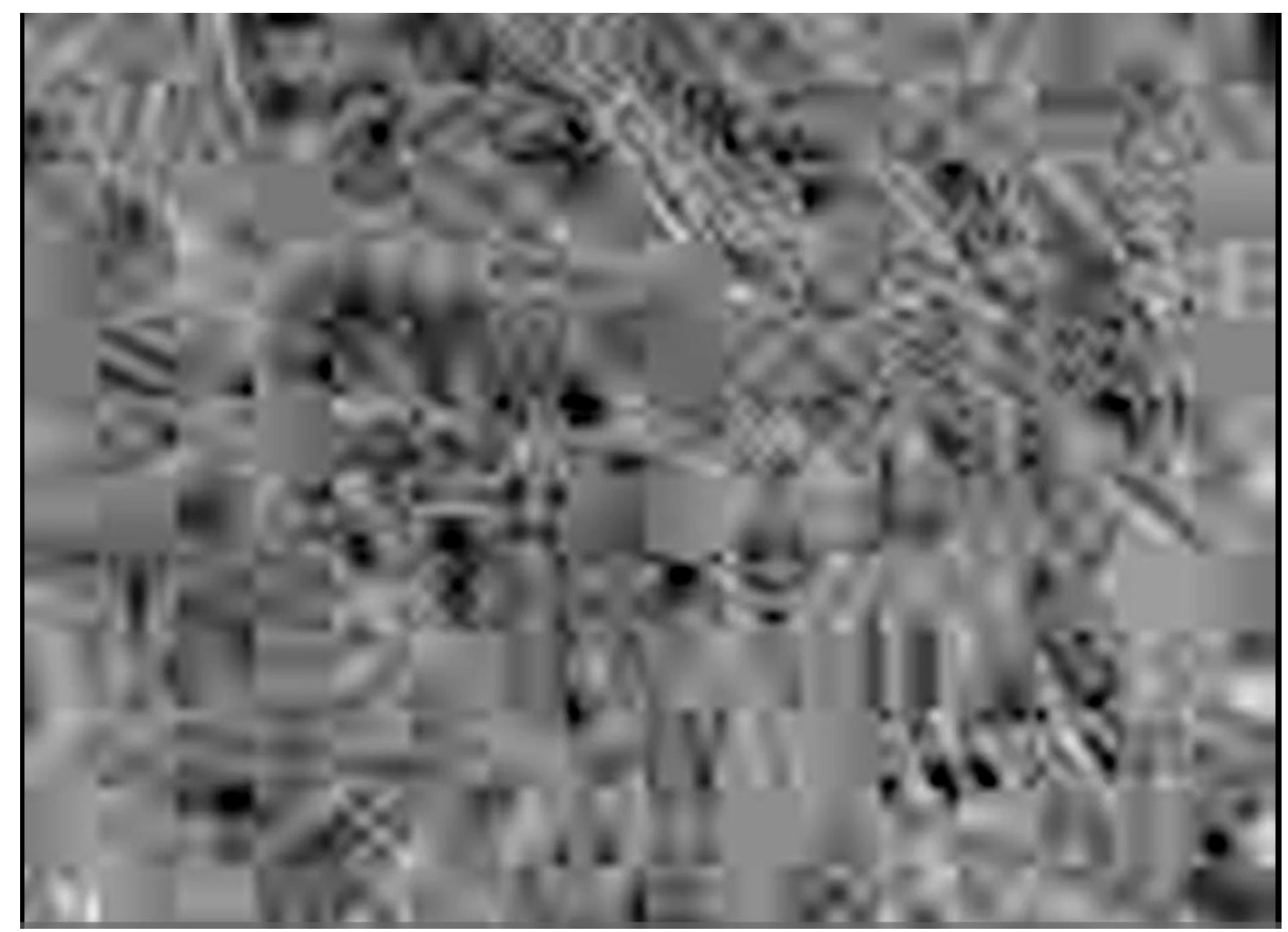

Figure 2. Tropic Pocket (Camilo Restrepo, 2011). Extremely pixelated mobile phone footage which seems to record the aftermath of a violent attack.

Restrepo has described Tropic Pocket as "a documentary against the document". ${ }^{25}$ However, after the intensity of the finale, the credits offer some documentary closure. Restrepo has 
included a brief description of each source as a sort of archival footnote. These notes, to some extent, explain the images, and thus dissipate their strangeness. They are partially recuperated for the audience's knowing gaze. In these acknowledgements, Restrepo does not reference the digital mediation of the older films, but he does draw attention to the role of online video in the armed conflict, where "the manipulation of truth through the use of images has now become an ordinary weapon for any soldier and any fighter", as the credit slide puts it. This moves away from a critique of the digital image as pure simulacrum, and instead points to a more materialist focus on the circulation and instrumentalisation of these images. By retaining the traces of the images' transit through non-professional digitisation and small-gauge analogue formats, Restrepo's film gives an account of his situated encounter with these archives. This refusal to abstract the archival image from its material context, even while questioning its indexicality, is a characteristic that Tropic Pocket shares with the other works I will discuss.

\section{The Labyrinth: Dialectics of fantasy}

Laura Huertas Millán's short film The Labyrinth (2018) is part of a series of works that she calls "ethnographic fictions". Drawing on Jean Rouch's notion of "ethno-fictions", these works engage with contemporary ethnographic practices, while also treating ethnography as a discursive system imbued with fiction:

On the one hand, if one considers ethnography as an ensemble of narratives rooted in colonialism, it can be understood as a kind of fiction-making. On the other, some of the most interesting contemporary practices of ethnography have embraced a decolonial turn, sometimes by integrating the language of fiction into themselves. ${ }^{26}$

The Labyrinth is constructed around a voiceover testimony by Cristóbal Gómez Abel, who recounts his time working for drug trafficker, Evaristo Porras. This narco famously had a house built to emulate the Carringtons' mansion from the TV series Dynasty (ABC 1980-1989). The film informs the viewer that Porras died penniless and the house, in the Amazonian city of 
Leticia, is now a crumbling ruin. The image track initially alternates between colour $16 \mathrm{~mm}$ footage of these ruins and clips from Dynasty. The final section of the film then goes into the jungle and into the night with Cristóbal as he recounts his visions during a near-death experience. While Huertas Millán’s 16mm cinematography is saturated with the texture and colour of walls, vegetation, water and fire, the film follows Cristóbal between spaces that are all in some way beyond reality. The house is a failed fantasy, a copy of a copy, insofar as it is a simulacrum of the spectacular spaces of the Dynasty mansion. Cristóbal's vision, on the other hand, remains unrepresented. The beautiful white space he describes is not available for the viewer's consumption.

In a talk at the Cinemateca de Bogotá in 2021, film critic Pedro Adrián Zuluaga introduced a fragment of The Labyrinth as an example of a form of emancipatory cinema that could offer paths of resistance to the planned obsolescence and extractive drive of capitalist imagemaking. ${ }^{27}$ The global media's avid consumption of Colombia's cocaine trade stories is an example of Zuluaga's "transnational economy of the ruin", with the countless Netflix documentaries about Pablo Escobar's hippos and other excesses a case in point. The Labyrinth could be one such story, but instead the film centres Cristóbal's agency and the reclamation of the house by people, plants, and animals. The narco story is told simply as a workplace situation, albeit a particularly dangerous one, and the ruin is another quotidian space rather than a romantic symbol. It does, however, exist in dialogue with the symbolic, and particularly with Dynasty as an example of the legitimating fantasies of extractive capitalism.

A family melodrama centred on the Denver oil magnate Blake Carrington (John Forsythe) and his wife Krystle (Linda Evans), Dynasty had top ratings in the US by 1984, while it was also being broadcast in over 75 countries. ${ }^{28}$ The show's representation of affluence has been linked to the entrenchment of consumerism during the Reagan era, even though the storylines 
ostensibly presented corporate greed as immoral. ${ }^{29}$ For international audiences Dynasty could function as a representation of US lifestyles, ${ }^{30}$ an aspirational slice of the American dream that obscured the realities of poverty and inequality, as well as underplaying the centrality of oil. In Dynasty, oil is a source of personal wealth but also a necessary material for a lavish lifestyle, demonstrating the mutual implication of extractivism and consumerism.

The Labyrinth contrasts the American petro-dream and its tropical simulacrum, often in humorous ways, by swapping the soundtracks. In some sections, the overwrought dialogue and string music from the TV show plays over the $16 \mathrm{~mm}$ footage of Porras's abandoned house. The artificial intensity of the soap opera is exposed as absurd through its juxtaposition with the organic and the mundane: a man walking through the jungle, a puddle with rubbish floating on it, an iguana making an escape. In other sections, the image track shows clips from the TV series, focusing on the mansion that Porras was trying to copy. Cristóbal's testimony about the cocaine-laden tables and barbecue parties for army accomplices plays over repeated angles of the Dynasty house and garden. As the luxury of ballrooms, dining halls and diamond necklaces is paraded on screen, Cristóbal describes the mortal risks for ordinary coca farmers working for the cartel: "If they owed you a million pesos, or two, rather than pay you, they would send someone to bump you off'. Meanwhile, on-screen, Krystle stands alone on a balcony, as if in a gilded cage. 


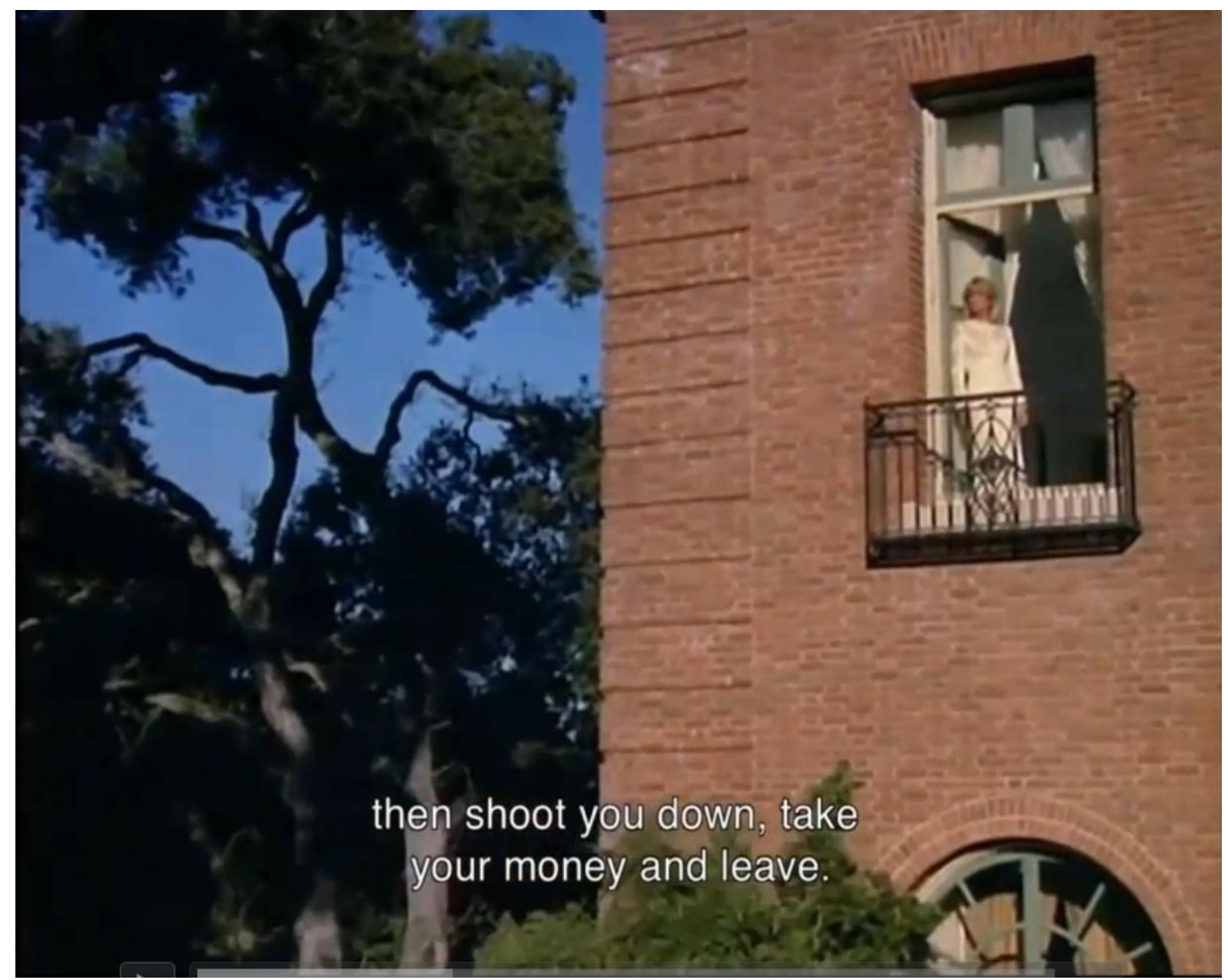

Figure 3: The Labyrinth (Laura Huertas Millán, 2018). Scene from Dynasty (ABC 1980-1989). Krystle (Linda Evans) and the Carrington house, overlaid with Cristóbal's testimony on the soundtrack and subtitles.

Then comes a short, striking sequence, with ten shots of oil drilling machinery towering against the sky, and then one image of a drilling tower exploding and collapsing. Appearing immediately after Cristóbal's story of exploitation by cartel henchmen, this sequence connects their violence to that of oil barons, whose lifestyles provided an aspirational model for drug traffickers as they embarked on their own practices of extraction. As Erika Balsom writes,

Between Colombia and the United States, cocaine and oil, reality and television, multiple narratives intersect in a nexus of affluence, aspiration, and violence [...] creating an accord between the violence of the drug wars, the violence of European conquest, and possibilities of survival and resistance against both. ${ }^{31}$

A later sequence presents a succession of cars and planes, gliding across all-American landscapes as Cristóbal recounts his childhood, hunting and fishing on the riverbank. His sense 
of autonomy and the ease with which he moves around the territory, on foot or canoe, express an alternative to the spectacular promises of petroculture and petromodernity. ${ }^{32}$ This resistance is not fetishised in an ethnographic fantasy of purity, but set alongside the material trappings of the oil baron lifestyle, in a continuum of relationships to the land.

The Labyrinth's aesthetic strategies overlap with those in Tropic Pocket, using analogue filmmaking, found footage, and soundtrack transpositions to propose a critique of colonial gazes. The coloniser's fantasies, materialised in the petroimages of consumerist excess, are put to work against themselves. Hyperreal gilded mansions aspire to transcendence but are reclaimed by the jungle, like the Chevrolet Corvair abandoned in the Darién gap, which is the last image in Tropic Pocket. Huertas Millán's choice to engage with an American soap opera that does not bear an explicit relationship to the Colombian context is radical, because it returns the ethnographic gaze back on the coloniser. It engages with Reaganite petroculture as a kind of "fiction-making", like colonial ethnography. By realising the inseparability between affluence and violence, between oil barons and narcos, and between popular media ideologies and real lives, the film refuses to commodify Cristóbal's testimony.

\section{Oslo, 2012: Mediation and direct experience}

While Restrepo and Huertas Millán work with found footage in the public domain, there is also a strong presence of home movies and the private archive in recent work by Colombian filmmakers. Ranging from experimental to mainstream documentary, works by Juan Soto, Daniela Abad, Andrea Said, Federico Atehortúa, Mercedes Gaviria, and Marta Hincapié, amongst others, have engaged with their own family archives as a means of exploring questions of memory and history. Home movies and family photographs have had a growing presence in Latin American filmmaking since the 1980s. ${ }^{33}$ The work of filmmakers like Albertina Carri and Andrés di Tella has been cited by their Colombian counterparts with 
appreciation for the reflective approaches to the archive. ${ }^{34}$ In the works that I study here, the personal archive works side by side with television news footage to make explicit the distance between the two, which in turn is a reflection on situated experiences of the Colombian conflict. This reflexivity serves again to counter extractive approaches to the archive, by giving back other images and by questioning the filmmaker's right to tell certain stories, as well as the audience's right to consume them. If the ethnographic and the extractive gazes are characterised by the erasure of their subjective standpoints, reflexivity can offer paths of resistance.

Speaking about his film Pirotecnia [Mute Fire] (2019), Federico Atehortúa reflected on his initial attempt to make a documentary about the "false positives" (thousands of cases of civilians murdered by the army and falsely presented as enemy combatants in order to obtain perks and rewards). ${ }^{35}$ Atehortúa recognised that he "felt limited when [he] approached this topic as [he] didn't feel authorised to talk about this". ${ }^{36}$ A semi-fictionalised personal narrative about a family illness then becomes a way into the topic, framing a reflection on the function of images throughout the Colombian conflict. By positioning himself as a spectator rather than a victim, Atehortúa finds a standpoint from which to engage with the archive, which ultimately tells a story about representation rather than violence. There is a similar unease in Marta Hincapié's Las razones del lobo [The wolf's reasons] (2020), which refers to the conflict in the voiceover narration without showing its images, presenting instead the calm pools and manicured lawns of a country club. These films express a structural unease about the positionality of representation and the expectation that Colombian filmmakers will speak from direct traumatic experience. The films reflect on mediated witnessing while refusing to perform first-hand trauma or to appropriate victims' narratives. This refusal is an attempt to acknowledge and be accountable for structural differences in the conflict's impact across class divides. Aside from the heightened terrorism stage of the drug wars in the 1980s and 1990s, 
the Colombian conflict has mostly played out in rural areas and urban peripheries. Therefore, it was possible for children of the middle and upper-middle classes - those most likely to have home videos to look back on - to grow up experiencing war mainly as an ongoing televised event.

For filmmakers of this generation and background, questioning this perspective is ethically crucial, but it risks reifying the distance it observes. Writing on "elite capture", Olúfémi O. Táíwò warns against the "deferential" application of standpoint epistemology, as "it focuses us on the interaction of the rooms we occupy, rather than calling us to account for the interactions we don't experience". ${ }^{37}$ In the ethical attempt to avoid speaking on behalf of others, there may be a risk of assuming a separation that ignores mutual implication and responsibility. In Colombia, there is no experience that is completely outside that of conflict. As Camilo Restrepo argues, even international law has recognised the collective victimhood of Colombians, and hence, he says, "I would like to avoid that common thought that considers that only having experienced violence validates one's interest in the topic". ${ }^{38}$ Extensive research with secondary sources and witness testimony allows the filmmaker to inhabit other perspectives without mimicry, by recognising their own position as fragmentary.

Distance from the conflict is, in any case, always relative and provisional. In Juan Soto's short film Oslo, 2012, shifting positions of proximity and mediation play out across a range of registers, from the home video to the television archive. The video starts with a warning that it is "for Colombians only" and a mise-en-abyme where Soto films his own computer screen in a flat in Berlin. The film's title alludes to the start of the peace dialogues with FARC in the Norwegian capital in October 2012. At this inflection point in the long history of conflict, the film offers an analysis of some of the intractable obstacles on the way to peace, central amongst them the United States' historical role in Colombian politics, played out in the pageantry of US 
presidential visits that have served to cement extractivist trade agreements and military support with unspoken links to paramilitary violence.

Oslo is a dense collage of moving images and sounds gleaned from nearly a century of representations of the Colombian conflict, from the 1927 anti-imperialist feature Garras de Oro [a.k.a. The Dawn of Justice] ${ }^{39}$ to a 2007 animation criticising the "phony demobilization" of paramilitaries, who were granted immunity and allowed to rearm. ${ }^{40}$ The never-ending cycle of violence is punctuated by the state visits, captured on film and video in all their obsequiousness. At the core of the film is the 2007 meeting between George W. Bush and Alvaro Uribe, and the protests that surrounded it. The framing of this moment moves across a proliferating number of perspectives. There is the predictable news footage of pomp and ceremony, but as the national anthem plays, Soto cuts to digital video footage of the police detaining a group of young protesters as the presidential visit plays on TV. First, the television set at the detention place foregrounds the mediation that both separates and links the state visit with the act of police repression. Then, another frame appears showing this protest footage playing on a computer media player. Showing the media interface again makes explicit a second-hand perspective, which is then complicated because the filmmaker himself can be seen in the footage, holding a video camera. This is a second-hand account of an event at which the filmmaker was present, which both legitimates and fragments the veracity of the reportage. 


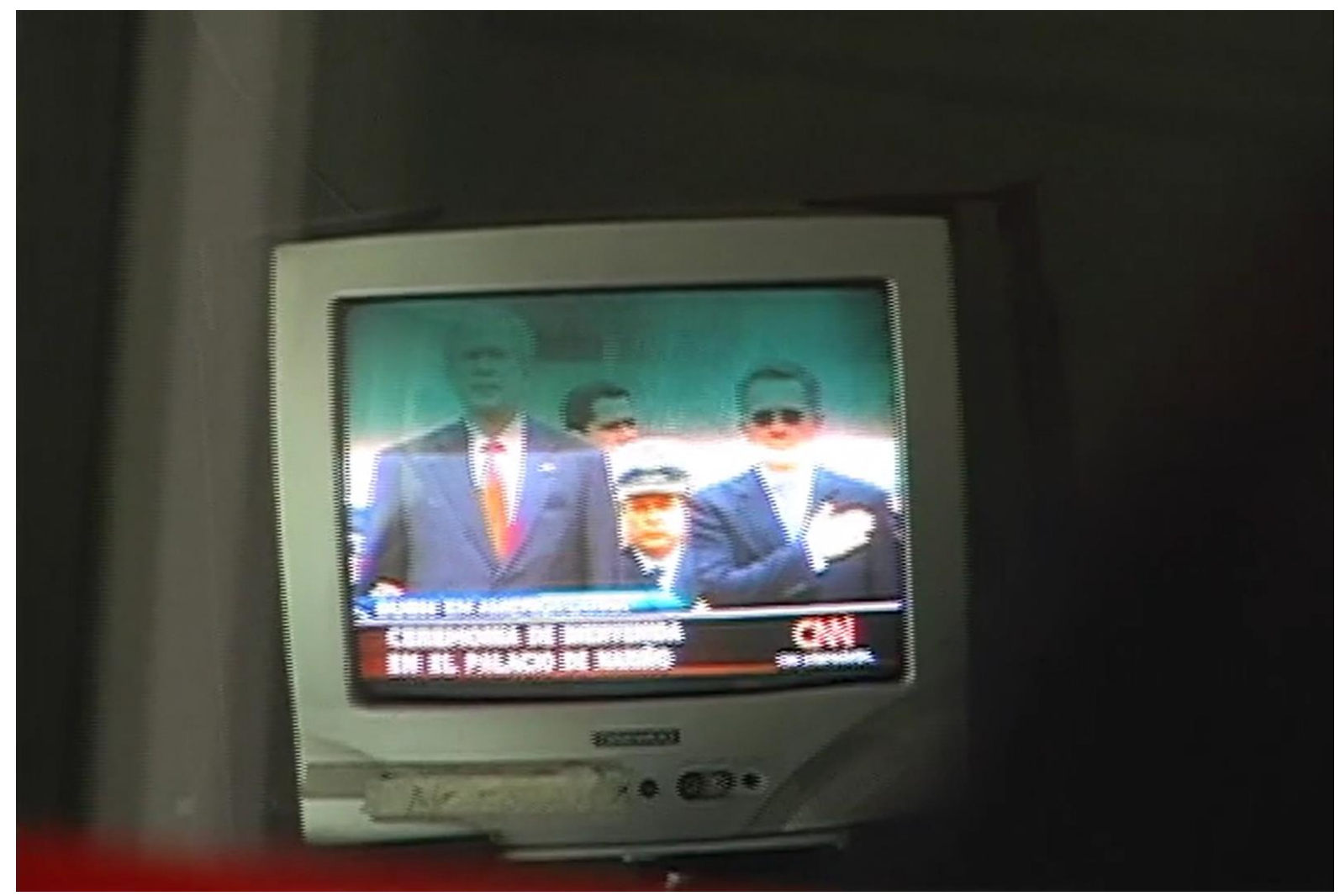

Figure 4: Oslo, 2012 (Juan Soto, 2014). A TV news broadcast shows Alvaro Uribe standing next to George W. Bush during the US president's visit to Colombia in 2007.

The following section appears more immediate, intercutting protest scenes and chants with black-and-white footage of $20^{\text {th }}$-century crowds and with the official ceremony, until the "Stars and Stripes" is interrupted by a transition to riot police firing tear gas. The camerawork becomes frantic as the filmmaker has to escape the gas and negotiate an intimidating encounter with a policeman who will not allow filming. This direct experience of repression gives way again to the archive, with news footage assembled into a harrowing sequence of dead bodies that tracks back through the decades. The sequence has a troubling abstract quality, where abject images of the dead stand in for the violence of each decade. Amongst these images, repeated twice, is a piece of footage that is as recognisable for Colombians as the Zapruder footage is to Americans: the confused moments after presidential candidate Luis Carlos Galán was gunned down while taking the stage at a campaign rally in 1989. This becomes an anchor point for the legibility and temporality of the other, less famous images. 


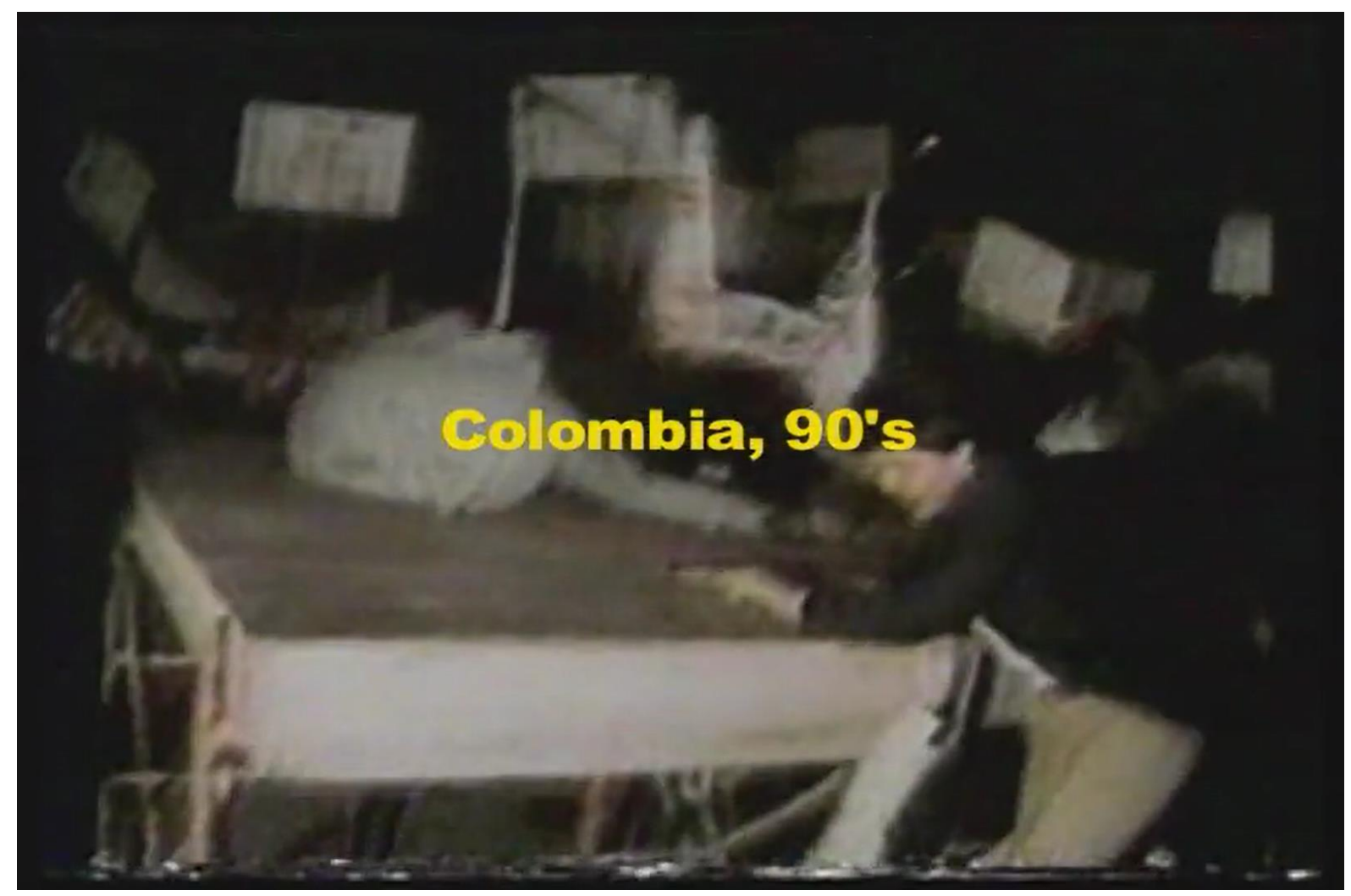

Figure 5: Oslo, 2012 (Juan Soto, 2014). News footage of Luis Carlos Galán’s assassination in 1989.

The voiceover talks about the systematic extermination of the socialist political party Unión Patriótica (UP), by state forces and allies, as a condensation of Colombia's inability to sustain the conditions for peace. In other films, Soto has explored the victimisation of members of his own family who were connected to this political party. $19^{\circ}$ Sur $65^{\circ}$ Oeste (2010) deals with the forced exile of one of Soto's relatives, and Parábola del Retorno (2016) takes the imagined perspective of another one, who worked as a bodyguard to the UP's presidential candidate, before being disappeared in 1987 . The archival news footage is thus inseparable from family history and from Soto's own relationship to it. This is, however, not explicit unless the viewer already knows this. An extra-textual or inter-textual understanding of the filmmaker's own personal and political position thus becomes determinant for the interpretation of this sequence as distanced or intimate. Without it, the explicit footage of victims of violence risks being received as generic and sensationalist, in keeping with its television news sources. 
At the start of the film, Soto declares he is making "a self-portrait". Besides the media player sequence mentioned above, Soto appears on screen as a boy in a home video dated 1997 , learning to dive in a swimming pool. The assumed innocence of the family video, edited in parallel to news clips about insurgent attacks and paramilitary massacres, speaks to the confusing experience of growing up in Colombia in the 1990s. In the swimming pool, metonymic for a family holiday, Soto appears carefree, while the montage demonstrates the intensity of war during that period. Nine years later, he is filming as he runs away from tear gas on the streets of Bogota. Five years after that, he is staring out of an apartment window in Berlin, where he is assembling this film. As Juana Suarez has observed, "central to Soto's work is an equation between editing a film and editing life". ${ }^{41}$ Laura Correa and Juan Osorio note that, through his editing, Soto "not only reviews the past but reviews himself, as a way of seeing himself implicated in the images he appropriates". ${ }^{42}$ This implication is unstable, producing a play between proximity and distancing, where the filmmaker reflects on shifting positions and relationships to Colombian events, as first-hand participant, victim, second-hand TV viewer, or distant observer.

This fragmented positionality corresponds to the "dislocations of the national" that Suárez has found in this group of Colombian filmmakers working abroad. ${ }^{43}$ Theirs is not an experience of exile but of relative mobility. Like Restrepo and Huertas Millán, Soto moves between Colombia and Europe (though not without the difficulties and barriers that colonial borders impose on Global South citizens). His films often combine footage shot in different countries, but also mediated accounts of events in Colombia as seen from afar. ${ }^{44}$ The uses of archival images introduce another layer of distance, both through their temporal disparity and through their marking as media discourses, seen on television or digital screens. Oslo, 2012 is not an archive compilation, but an account of the filmmaker's encounter with archives, including his own. Like in Tropic Pocket, the mediations that bring together digitised analogue film and 
television with non-professional home video formats are exposed, but the discontinuities are emphasised.

Filming a TV news broadcast as it is being watched on a TV set is a way to explain the filmmaker's distance from the event, and thus to refer to violence without appropriating it. This can then be another way of resisting or derailing extractive uses of the archive. In Las razones del lobo, Marta Hincapié also includes the TV news playing in a country club room, bright and sterile, while a toilet can be heard to flush in the background. The final sequence of the film could be a reverse shot to this setup: María Teresa Uribe, Hincapié's mother, who is both the protagonist of many of the stories told in the film, and a scholar of violence in her own right, is watching the news about the referendum defeat of the peace agreement in 2016. "This is a national tragedy", she tells her daughter, "This is like a nightmare". Suddenly, the quiet scene is invaded by the overwhelming noise of explosions. In the streets, people are celebrating the referendum results, confirming their allegiance to violence. What seemed like a distant reality from the comfort of the club reasserts itself, first as mediated information (in the voice of a well-known news anchor) and then loudly, inescapably.

\section{Conclusion}

Archive filmmaking is a process of reappropriation. Theories of extractivism can, therefore, provide tools for a critical approach to these films. Colombia's cinematic image abroad has been dominated by violence and poverty, alongside touristic visions of a rich biodiversity ripe for the taking. However, Colombian filmmakers have long struggled with these tropes, negotiating expectations internally and abroad about how the country is to be represented. As Zuluaga argues, "memory, ruin and archive appear as dominant discourses of Colombian documentary", which sometimes grants the archive an unproblematic, positivist evidentiary value. ${ }^{45}$ Instead of assuming the transparency of historical footage, filmmakers like Restrepo, 
Huertas and Soto have found ways to interrogate "a dispersion of ruins and signs" that refuse to package both landscape and history as consumable spectacles. This questioning proceeds through different strategies, some of which have been explored in this article.

Camilo Restrepo takes images constructed from a colonial gaze and disrupts them through juxtaposition, finding points of resonance, and using the surface distortions of informal digital archives to disclose his own archival pathways. This serves to question what is in the archive - or, rather, in the non-archival repositories of internet video - and how it was created. The multiple transits between analogue and digital formats invert assumptions of legibility, as the newer images are rendered more enigmatic than the older ones with which they are in dialogue. This refuses to see the colonial gaze as a historical artifact, and instead recognises it as a structuring pattern that persists even in the filmmaker's own approach to the topic.

Laura Huertas Millán uses an unexpected source, an American melodrama, which, placed alongside the more traditional oral testimony, allows her to establish a dialectical relationship between Colombia's drug trade, American consumerism, and more traditional extractive industries. Like Tropic Pocket, The Labyrinth performs its critical operations through montage, but rather than disrupting the surface of the image, Huertas Millán challenges the positivist impulse of documentary by weaving it together with fiction. In this approach, testimony and fantasy are different regimes of knowledge that sustain ways of being in the world.

Juan Soto uses his own archive to produce a reflective and eclectic approach to history, focusing on US-Colombia relationships and interweaving first- and second-hand accounts of events. The news footage is framed and reframed as mediated representation, drawing attention to their material devices and formats. The autobiographical approach to editing refuses to fill in the temporal gaps, offering a fragmentary, incomplete approach to history where the personal 
intersects with the collective only in flashes. The filmmaker's positionality is implicit but crucial to a non-sensationalist reading of the appropriated footage.

The use of archive footage in these works rejects the nostalgic or explanatory, refusing to render the past as linear, visible, and legible. This would seem like a promising site for forms of visuality that resist the extractive logic. While this article has identified practices of curation, intervention and montage used by the filmmakers studied, a materialist analysis of these films needs to go further, considering not only the sources of images, but their circulation and reception, as Juana Suárez starts to do in the closing section of her 2019 article. There are important questions to be asked about how the audio-visual memory of the Global South is kept, cared for, shared, and made available for appropriation. As digitisation speeds up the transnational movement of images and sounds, there are opportunities for more critical film cultures that continue to challenge the hegemony of the commoditised image.

\section{Notes}

\footnotetext{
${ }^{1}$ Juana Suárez, "Dislocations of the National: Colombian Cinema and Intercultural Spaces," Journal of Latin American Cultural Studies 28, no. 4 (2020): 541-63, https://doi.org/10.1080/13569325.2020.1739007, 542.

${ }^{2}$ These are filmmakers who are aware and supportive of each other, who cross paths at festivals and are often brought together by curators. In 2018, for instance, Juana Suárez's "Against the National Project" programme, screened in Glasgow and Durham, included films by Soto, Huertas Millán, Restrepo, Guerrero and Gonzalo Escobar (Centre for Contemporary Arts, 2018). In a 2021 curatorial fellowship for Cinemateca de Bogotá, works by Huertas Millán and Restrepo were screened alongside the likes of Kevin Jerome Everson and Susana de Sousa Dias, as part of a reflection on memory, testimony and the ruin (Cartel Urbano, 2021)

${ }^{3}$ Alongside Suárez's work, which focuses on those filmmakers who live and work outside Colombia, other authors propose different clusters. For instance, Diana Cuéllar places the work of filmmakers such as Restrepo and Guerrero within a tradition of "documentaries of dissent", alongside the political video-art works of Oscar Campo and Claudia Salamanca. Guerrero and Campo are also studied by Carolina Sourdis and María Luna in their work on found footage practices, alongside works by Luis Ospina and others. Diana Patricia Cuéllar España, "Documental del disenso: Representación de la violencia contemporánea en Colombia" (Madrid, Universidad Carlos III, 2019); Maria Luna and Carolina Sourdis, "Colombian Found Footage: The Tradition of Rupture," New Cinemas 13, no. 1 (March 2015), https://doi.org/info:doi/10.1386/ncin.13.1.51_1, 54.

${ }^{4}$ María Luisa Ortega, "El Mañana Empezó Ayer. Tradiciones y Rupturas En El Documental de América Latina," in Territorio y Memorias Sin Fronteras: Nuevas Estrategias Para Pensar Lo Real (Bogota: Uniminuto, 2021), 23-46., 26. [Author's translation]
} 
${ }^{5}$ Maria Luna and Carolina Sourdis, "Colombian Found Footage: The Tradition of Rupture," New Cinemas 13, no. 1 (March 2015), https://doi.org/info:doi/10.1386/ncin.13.1.51_1, 54.

${ }^{6}$ Luisa Fernanda Ordóñez Ortegón, El Archivo Audiovisual y la Escritura de la Historia (Bogotá: Cinemateca Distrital; Idartes, 2020), p. 113 [Author's translation]. A range of approaches to archives in Latin American cinema are represented in Mauricio Durán Castro and Claudia Salamanca, eds., Archivo, Memoria y Presente En El Cine Latinoamericano, 1st ed. (Bogotá: Pontificia Universidad Javeriana, 2016), https://doi.org/10.2307/j.ctv8xngsg.

${ }^{7}$ Luna and Sourdis, 54.

${ }^{8}$ Suárez 2019, 542.

${ }^{9}$ Gonzalo Sánchez Gómez, Caminos de Guerra, Utopías de Paz: Colombia: 1948-2020 (Bogota: Editorial Planeta, 2021), 10.

${ }^{10}$ Jaimie Baron, "The Archive Effect: Archival Footage as an Experience of Reception," Projections 6, no. 2 (November 15, 2012): 102-20, https://doi.org/10.3167/proj.2012.060207.

${ }^{11}$ Maristella Svampa, Neo-Extractivism in Latin America: Socio-Environmental Conflicts, the Territorial Turn, and New Political Narratives, Cambridge Elements. Elements in Politics and Society in Latin America (Cambridge: Cambridge University Press, 2019), 7.

${ }^{12}$ Imre Szeman and Jennifer Wenzel, "What Do We Talk about When We Talk about Extractivism?," Textual Practice 35, no. 3 (March 4, 2021): 505-23, https://doi.org/10.1080/0950236X.2021.1889829, 506.

${ }^{13}$ Macarena Gómez-Barris, The Extractive Zone: Social Ecologies and Decolonial Perspectives, Dissident Acts (Durham, NC and London: Duke University Press, 2017), p. 5.

${ }^{14}$ Szeman and Wenzel 2021, 511.

${ }^{15}$ Suárez 2019, 554-555.

${ }^{16}$ Janet Stewart, "Visual Culture Studies and Cultural Sociology: Extractive Seeing," in Sage Handbook of Cultural Sociology, ed. David Inglis and Anna-Mari Almila, 2016, p. 331

${ }^{17}$ Gómez-Barris 2017, 10.

${ }^{18}$ Suárez 2019, 558.

${ }^{19}$ At the time of writing, fragments of this film could be viewed on Universidad Tecnológica del Choco's YouTube channel (e.g. Part 1 https://www.youtube.com/watch?v=Lz-qcLkdi0o). The university supports the regional film and photo archive (Archivo Fotográfico y Fílmico del Chocó) and in 2006 published research on this film as part of a cinema history report by Gonzalo Díaz Cañadas.

${ }^{20}$ Brian Oakes, "Building Films for Business: Jamison Handy and the Industrial Animation of the Jam Handy Organization," Film History 22, no. 1 (2010): 95-107, https://doi.org/10.2979/fil.2010.22.1.95; Rick Prelinger, "Eccentricity, Education and the Evolution of Corporate Speech: Jam Handy and His Organization," in Films That Work, ed. Vinzenz Hediger and Patrick Vonderau, Industrial Film and the Productivity of Media (Amsterdam University Press, 2009), 211-20, https://www.jstor.org/stable/j.ctt45kdjb.16.

${ }^{21}$ Jaimie Baron, The Archive Effect: Found Footage and the Audiovisual Experience of History (Oxford: Routledge, 2014), 8.

${ }^{22}$ Camilo Restrepo, "Líneas de errancia: despliegue espacial en el montaje audiovisual," Cuadernos de cine colombiano, no. 30 (2020): 16-27, 20.

${ }^{23}$ Suarez 2019, 554

${ }^{24}$ Diana Kuéllar, "Camilo Restrepo, un cineasta del disenso," Nexus Comunicación, no. 27 (2020), https://doi.org/10.25100/nc.v0i27.10569, 15.

${ }^{25}$ Restrepo 2020, 21.

${ }^{26}$ Laura Huertas Millán, "In conversation”, Tank magazine, Issue 82 (2020), p. 17-18 https://www.laurahuertasmillan.com/ethnographic-fiction

${ }^{27}$ Pedro Adrián Zuluaga, "Estéticas de La Ruina y La Precariedad En El Cine Colombiano Contemporáneo" (Estudio de Campos, Cinemateca de Bogotá, May 22, 2021), https://www.youtube.com/watch?v=G-y-Fu0APU8. 28 “"Dynasty' Overseas” Variety, 315:6 (1984), 62.

${ }^{29}$ Jane Feuer, Seeing Through the Eighties: Television and Reaganism (Durham, NC: Duke University Press, 1995), p. 131. Gabriele Kreutzner and Ellen Seiter, "Not All 'Soaps' Are Created 
Equal: Towards a Crosscultural Criticism of Television Serials," Screen 32, no. 2 (July 1, 1991): 15472, https://doi.org/10.1093/screen/32.2.154., 167.

${ }^{30}$ Jennifer M. Keane-Dawes, "(Mis)Perception of American Media Reality: Narrating Dissonance in the Actuality of Cultural Assimilation," in Re-Constructing Place and Space: Media, Culture,

Discourse and the Constitution of Caribbean Diasporas, ed. Kamille Gentles-Peart and Maurice L. Hall (Newcastle upon Tyne: Cambridge Scholars Publishing, 2012), 33-52., 33-34.

${ }^{31}$ Erika Balsom, "Speaking into Being: The Ethnographic Fictions of Laura Huertas Millán," Text written for the individual exhibition The spring song. le chant du printemps, Maison des Arts, Centre d'art contemporain de Malakoff, 2018, https://www.laurahuertasmillan.com/speak-into-being.

${ }^{32}$ Belinda Smaill, "Petromodernity, the Environment and Historical Film Culture," Screen 62, no. 1 (April 8, 2021): 59-77, https://doi.org/10.1093/screen/hjab002.

${ }^{33}$ Jorge Ruffinelli, "Del Cine Doméstico al Documental Personal En América Latina. Cinco Casos," in La Casa Abierta: El Cine Doméstico y Sus Reciclajes Contemporáneos (Madrid: Ocho y Medio, 2010), 225-50, 225.

${ }^{34}$ Federico Atehortúa in conversation with María Paula Lorgia, Cinemateca de Bogotá, \#CineClubCinemateca: Pirotecnia (Dir. Federico Atehortúa Arteaga), 2020,

https://www.youtube.com/watch?v=VPcr8Dee3k8.

35 "Ejecuciones Extrajudiciales En Colombia 2002-2010" (Bogotá: Observatorio de derechos humanos y derecho humanitario, 2013), 7.

${ }^{36}$ Atehortúa in conversation with Lorgia, 2020.

${ }^{37}$ Olúfémi O. Táíwò, "Being-in-the-Room Privilege: Elite Capture and Epistemic Deference," The

Philosopher 108, no. 4 (Autumn 2020), https://www.thephilosopher1923.org/essay-taiwo.

${ }^{38}$ Diana Kuéllar, "Camilo Restrepo, un cineasta del disenso," Nexus Comunicación, no. 27 (2020): 117, https://doi.org/10.25100/nc.v0i27.10569, 13.

${ }^{39}$ Juana Suárez and Ramiro Arbeláez, "Garras De Oro (The Dawn of Justice—Alborada De Justicia): The Intriguing Orphan of Colombian Silent Films," trans. Laura A. Chesak, The Moving Image 9, no. 1 (2009): 54-82, https://doi.org/10.1353/mov.0.0034.

${ }^{40}$ Marc van Gurp, 'Colombia Clean', Osocio, 2007, https://osocio.org/message/colombia-clean/.

${ }^{41}$ Juana Suárez, "Cine 'nacional'/circulación transnacional: la experiencia fílmica colombiana en el extranjero en años recientes," Nexus Comunicación, 2016, 6-23,

https://doi.org/10.25100/nc.v0i19.661, 18.

${ }^{42}$ Laura Correa Montoya and Juan Osorio Villegas, "El Desplazamiento de La Mirada. En $19^{\circ}$ Sur $65^{\circ}$ Oeste, Oslo, 2012 y Parábola Del Retorno, de Juan Soto," in Territorios y Memorias Sin Fronteras, ed. María Luna, Pablo Mora, and Daniela Samper (Editorial Pontificia Universidad Javeriana, Corporación Universitaria Minuto de Dios -UNIMINUTO, Alados, 2021), 167-94. ${ }^{43}$ Suárez 2019, 542.

${ }^{44}$ For instance, Soto's 2020 film, Revelaciones, is mainly structured around a long telephone conversation with his mother as she drives on a Colombian road during one of the days of a national strike. Through her account, both the filmmaker and the viewer have access to an ordinary experience during an important historical moment.

${ }^{45}$ Pedro Adrián Zuluaga, "Asedios a Las Ruinas En El Documental Colombiano Contemporáneo," in Territorio y Memorias Sin Fronteras: Nuevas Estrategias Para Pensar Lo Real (Bogota: Uniminuto, 2021), 147-67. 155.

\section{Filmography}

Atehortúa, Federico. Pirotecnia. Invasión Cine, 2019.

Hincapié Uribe, Marta. Las razones del lobo. Sandelion Producciones, 2020. 
Huertas Millán, Laura. The Labyrinth. 2018. Source: SAVVY Contemporary, https://vimeo.com/500803326, last accessed November 2021.

Jam Handy, Daring the Darién! Chevrolet Motor Division, 1962.

Martínez Velasco, Alfonso [as P.P. Jambrina] Garras de Oro / Alborada de Justicia. Cali Film, 1927.

Restrepo, Camilo. Impression of a War. 529 Dragons, 2015.

Restrepo, Camilo. Los Conductos. Montañero Cine If You Hold A Stone, 2020.

Restrepo, Camilo. Tropic Pocket. Mutokino / Collectif Jeune Cinéma, 2011. Source: https://kinoscope.org/v/tropic-pocket/, last accessed November 2021.

Restrepo, Jorge. La Isla de los Deseos. Misioneros Claretianos, c. 1958.

Soto Taborda, Juan. $19^{\circ}$ Sur $65^{\circ}$ Oeste, 2010.

Soto Taborda, Juan. Oslo, 2012. 2014. Source: Artist's website. https://www.juansoto.co.uk/oslo-2012, last accessed November 2021.

Soto Taborda, Juan. Parábola del Retorno. Tardeotemprano Films, 2017.

\section{Bibliography}

“Ejecuciones Extrajudiciales En Colombia 2002-2010.” Bogotá: Observatorio de derechos humanos y derecho humanitario, 2013. https://coeuropa.org.co/wpcontent/uploads/2017/05/Documentos-tematicos-8-FINAL-1.pdf.

Balsom, Erika. "Speaking into Being: The Ethnographic Fictions of Laura Huertas Millán.” Text written for the individual exhibition The spring song. le chant du printemps, Maison des Arts, Centre d'art contemporain de Malakoff, 2018. https://www.laurahuertasmillan.com/speak-into-being. 
Baron, Jaimie. "The Archive Effect: Archival Footage as an Experience of Reception." Projections 6, no. 2 (November 15, 2012): 102-20. https://doi.org/10.3167/proj.2012.060207.

Baron, Jaimie. The Archive Effect: Found Footage and the Audiovisual Experience of History. Oxford: Routledge, 2014.

Cartel Urbano. "Relato Oral y Ruina,” November 28, 2021. https://web.archive.org/web/20211128184014/https://cartelurbano.com/eventos/agenda/ $\underline{\text { relato-oral-y-ruina-proyecto-curatorial-cinemateca-de-bogota. }}$

CCA Glasgow. "Against the National Project: Memory and Mobility in Contemporary Colombian Cinema," 2018. https://www.cca-glasgow.com/programme/against-thenational-project.

Correa Montoya, Laura, and Juan Osorio Villegas. “El Desplazamiento de La Mirada. En 19 Sur 65 Oeste, Oslo, 2012 y Parábola Del Retorno, de Juan Soto.” In Territorios y Memorias Sin Fronteras, edited by María Luna, Pablo Mora, and Daniela Samper, 167-94. Editorial Pontificia Universidad Javeriana, Corporación Universitaria Minuto de Dios -UNIMINUTO, Alados, 2021.

Cuéllar España, Diana Patricia. "Documental del disenso: Representación de la violencia contemporánea en Colombia.” PhD Thesis. Universidad Carlos III de Madrid, 2019. Díaz Cañadas, Gonzalo. “Historia Del Cine En El Chocò.” Quibdó: Universidad Tecnológica del Chocó, November 2006. https://es.slideshare.net/udelchoco/historia-del-cine-en-elchoc.

Feuer, Jane. Seeing Through the Eighties: Television and Reaganism. Durham, NC; Duke University Press, 1995.

Gómez-Barris, Macarena. The Extractive Zone: Social Ecologies and Decolonial Perspectives. Dissident Acts. Durham, NC and London: Duke University Press, 2017. 
Gurp, Marc van. 'Colombia Clean'. Osocio, 2007. https://osocio.org/message/colombiaclean/.

Huertas Millán, Laura. “In conversation”, Tank magazine, Issue 82 (2020), p. 17-18 https://www.laurahuertasmillan.com/ethnographic-fiction

Keane-Dawes, Jennifer M. “(Mis)Perception of American Media Reality: Narrating Dissonance in the Actuality of Cultural Assimilation." In Re-Constructing Place and Space: Media, Culture, Discourse and the Constitution of Caribbean Diasporas, edited by Kamille Gentles-Peart and Maurice L. Hall, 33-52. Newcastle upon Tyne: Cambridge Scholars Publishing, 2012.

Kreutzner, Gabriele, and Ellen Seiter. 'Not All ‘Soaps’ Are Created Equal: Towards a Crosscultural Criticism of Television Serials.” Screen 32, no. 2 (July 1, 1991): 154-72. https://doi.org/10.1093/screen/32.2.154.

Kuéllar, Diana. “Camilo Restrepo, un cineasta del disenso.” Nexus Comunicación, no. 27 (2020): 1-17. https://doi.org/10.25100/nc.v0i27.10569.

Luna, Maria, and Carolina Sourdis. "Colombian Found Footage: The Tradition of Rupture." New Cinemas 13, no. 1 (March 2015): 51-64. https://doi.org/info:doi/10.1386/ncin.13.1.51_1.

Mauricio Durán Castro and Claudia Salamanca, eds., Archivo, Memoria y Presente En El Cine Latinoamericano, 1st ed. (Bogotá: Pontificia Universidad Javeriana, 2016), https://doi.org/10.2307/j.ctv8xngsg.

Oakes, Brian. "Building Films for Business: Jamison Handy and the Industrial Animation of the Jam Handy Organization.” Film History 22, no. 1 (2010): 95-107. https://doi.org/10.2979/fil.2010.22.1.95.

Ordóñez Ortegón, Luisa Fernanda. El Archivo Audiovisual y La Escritura de La Historia. Bogotá: Cinemateca Distrital; Idartes, 2020. 
https://idartesencasa.gov.co/sites/default/files/libros_pdf/El\%20archivo\%20audiovisual _web\%20\%281\%29.pdf.

Ortega, María Luisa. “El mañana empezó ayer. Tradiciones y rupturas en el documental de América Latina." In Territorio y memoria sin frontera, edited by María Luna, Pablo Mora and Daniela Samper. 23-46. Bogotá: Uniminuto, 2021.

Prelinger, Rick. "Eccentricity, Education and the Evolution of Corporate Speech: Jam Handy and His Organization.” In Films That Work, edited by Vinzenz Hediger and Patrick Vonderau, 211-20. Amsterdam University Press, 2009. https://www.jstor.org/stable/j.ctt45kdjb.16.

Restrepo, Camilo. "Líneas de errancia: despliegue espacial en el montaje audiovisual.” Cuadernos de cine colombiano, no. 30 (2020): 16-27.

Sánchez Gómez, Gonzalo. Caminos de Guerra, Utopías de Paz: Colombia: 1948-2020. Bogota: Editorial Planeta, 2021.

Smaill, Belinda. "Petromodernity, the Environment and Historical Film Culture." Screen 62, no. 1 (April 8, 2021): 59-77. https://doi.org/10.1093/screen/hjab002.

Stewart, Janet. "Visual Culture Studies and Cultural Sociology: Extractive Seeing." In Sage Handbook of Cultural Sociology, edited by David Inglis and Anna-Mari Almila, 32234, 2016.

Suárez, Juana, and Ramiro Arbeláez. "Garras De Oro (The Dawn of Justice-Alborada De Justicia): The Intriguing Orphan of Colombian Silent Films.” Translated by Laura A. Chesak. The Moving Image 9, no. 1 (2009): 54-82. https://doi.org/10.1353/mov.0.0034. Suárez, Juana. "Cine 'nacional'/circulación transnacional: la experiencia fílmica colombiana en el extranjero en años recientes.” Nexus Comunicación, no. 19 (July 25, 2016): 6-23. https://doi.org/10.25100/nc.v0i19.661. 
Suárez, Juana. "Dislocations of the National: Colombian Cinema and Intercultural Spaces." Journal of Latin American Cultural Studies, April 28, 2020, 541-63. https://doi.org/10.1080/13569325.2020.1739007.

Svampa, Maristella. Neo-Extractivism in Latin America: Socio-Environmental Conflicts, the Territorial Turn, and New Political Narratives. Cambridge Elements. Elements in Politics and Society in Latin America. Cambridge: Cambridge University Press, 2019. Szeman, Imre, and Jennifer Wenzel. "What Do We Talk about When We Talk about Extractivism?" Textual Practice 35, no. 3 (March 4, 2021): 505-23. https://doi.org/10.1080/0950236X.2021.1889829.

Táíwò, Olúfémi O. "Being-in-the-Room Privilege: Elite Capture and Epistemic Deference.” The Philosopher 108, no. 4 (Autumn 2020). https://www.thephilosopher1923.org/essay-taiwo.

Zuluaga, Pedro Adrián. "Estéticas de La Ruina y La Precariedad En El Cine Colombiano Contemporáneo.” Beca de Curaduría, Estudio de Campos, Cinemateca de Bogotá, May 22, 2021. https://www.youtube.com/watch?v=G-y-Fu0APU8.

Zuluaga, Pedro Adrián. “Asedios a Las Ruinas En El Documental Colombiano Contemporáneo." In Territorio y Memorias Sin Fronteras: Nuevas Estrategias Para Pensar Lo Real, 147-67. Bogota: Uniminuto, 2021.

\section{Author Biography}

María A. Vélez-Serna is a lecturer in Film and Media at the University of Stirling, and a film school graduate from Universidad Nacional de Colombia. She is the author of Ephemeral Cinema Spaces (Amsterdam University Press, 2020) and co-author of Early Cinema in Scotland (Edinburgh University Press, 2018). 